\title{
Innovation in input supply systems in smallholder agroforestry: seed sources, supply chains and support systems
}

\author{
J. B. L. Lillesø • L. Graudal · S. Moestrup • \\ E. D. Kjær $\cdot$ R. Kindt $\cdot$ A. Mbora $\cdot$ I. Dawson $\cdot$ \\ J. Muriuki $\cdot$ A. Ræbild $\cdot$ R. Jamnadass
}

Received: 7 January 2011/Accepted: 25 June 2011/Published online: 7 July 2011

(C) The Author(s) 2011. This article is published with open access at Springerlink.com

\begin{abstract}
Institutional innovation in providing inputs and services is a central element for smallholder development. Agroforestry is an important income generating activity for millions of smallholders in the tropics, yet access to quality planting material-germplasm—of valuable tree species remains a major hurdle for improving farm productivity. We discuss requirements and possibilities for institutional innovation in developing more efficient delivery systems for tree germplasm as one aspect of improved input supply. We describe a simple model for delivery to farmers that identifies the major types of germplasm sources and discuss how this model can be used to identify relevant interventions to address bottlenecks in current systems. Our analysis leads to eight input supply configurations for
\end{abstract}

J. B. L. Lillesø $(\square) \cdot$ L. Graudal · S. Moestrup ·

E. D. Kjær · A. Ræbild

Forest and Landscape Denmark, Faculty of Life Sciences,

University of Copenhagen, Rolighedsvej 23, 1958

Frederiksberg C, Denmark

e-mail: jpbl@life.ku.dk

L. Graudal

e-mail: lgr@life.ku.dk

S. Moestrup

e-mail: smoe@life.ku.dk

E. D. Kjær

e-mail: edk@life.ku.dk

A. Ræbild

e-mail: are@life.ku.dk smallholder agroforestry, typified by three major models. Lessons from the evolution of smallholder crop seed delivery systems can be applied to tree germplasm supply and indicate that a commercial, decentralised model holds most promise for sustainability. However, current emphasis in agroforestry on government and NGO models of delivery hinder the development of this approach. The application of prevailing classification approaches may also create a barrier to the development of appropriate supply systems that effectively service smallholders. An important implication of our analysis is that current actors in agroforestry input supply systems must redefine their roles in order for effective delivery to take place. We chose a case study from Kenya to illustrate our points.

\author{
R. Kindt · A. Mbora - I. Dawson - J. Muriuki . \\ R. Jamnadass \\ The World Agroforestry Centre, Headquarters, \\ P.O. Box 30677, Nairobi, Kenya \\ e-mail: r.kindt@cgiar.org \\ A. Mbora \\ e-mail: a.mbora@cgiar.org \\ I. Dawson \\ e-mail: Iankdawson@aol.com \\ J. Muriuki \\ e-mail: j.muriuki@cgiar.org \\ R. Jamnadass \\ e-mail: r.jamnadass@cgiar.org
}


Keywords Agroforestry - Seed sources - Input supply chains · Public-private collaboration - OECD 'Forest Seed and Plant Scheme'

\section{Introduction: seed supply to smallholders is inefficient}

Agroforestry, the practice of integrating trees with annual crop cultivation and other farm activities, is an approach adopted by millions of tropical smallholders to meet their needs for essential resources of food, medicine, timber, fuel, fodder and market commodities, and provides valuable environmental services (Garrity 2004). Worldwide, approximately 560 million people live in agroforestry ecosystems with more than $10 \%$ tree cover, which equates to $31 \%$ of all humans inhabiting farmland (Zomer et al. 2009). Growing trees on farms has become part of the smallholder's investment strategy in agricultural enterprises along with annual crops. A lack of institutional innovation in input supply systems that could service smallholders has, however, been identified as a major problem for both crop and agroforestry seed systems for several decades (Graudal and Lillesø 2007; Hazell et al. 2007; Minot et al. 2007; World Bank 2007).

For crop seed systems, there has been heated debate over the decades in how to improve smallholder access to good planting material, and the new concepts from these discussions provide an insight into what institutional innovations may be possible for agroforestry seed delivery systems. This article has explored these issues further based on the following structure: "Introduction: seed supply to smallholders is inefficient" section presents an evolution of ideas and approaches for input supply systems for crops and for agroforestry, "A barrier for further development of agroforestry input supply systems" section summarises how the concepts applied to crop seed systems provide an understanding of the limitations of the prevailing classification of germplasm sources for agroforestry, "A classification of sources and input supply to better support smallholder agroforestry" section explains how these limitations may be overcome, "The Kenya case study" section applies our theoretical construct to an actual case study in Kenya; and "Discussion" section discusses the implications of our analysis.
Crop input supply systems

The evolution of ideas and approaches for delivering inputs for crop production in Africa and elsewhere in the tropics has gone through a number of (partly overlapping) phases. The first phase started in the 1970s, when governments and donors began to provide substantial support for crop seed system development by establishing parastatal seed breeding corporations, technical laboratories for quality control and seed certification authorities (Friis-Hansen 2000; Maredia et al. 1999; Tripp 2001; Wiggins and Cromwell 1995). For the majority of smallholders, however, the success of this formal system (we define the formal sector as being composed of public and private organizations with specialized roles in supplying new varieties; in contrast, the informal sector is made up of private households and NGOs) was limited to supplying hybrid maize and sorghum; it is estimated that parastatal seed systems supplied only about $10 \%$ of the total crop seed sown by smallholders each year (Maredia et al. 1999). Many seed parastatals were subsequently dissolved or privatised because they were seen as inefficient and too dependent on the state or on donor subsidies; the expectation was that seed supply would then be mainly carried out by private corporations. From the smallholder's perspective, however, there was no improvement in delivery, with access to improved seed of the diverse range of crop varieties that they required still limited.

To compensate for the poor performance of the formal seed sector, in a second phase many donors and policymakers switched support to non-governmental organisations (NGOs) to provide seed of nonhybrid crop varieties to smallholders (White and Eicher 1999). The approach was characterised by setting up community and village level 'micro' production of crop seeds, focusing on the technical aspects of seed production and then imitating formal models for seed distribution. The impact of this NGO approach was however limited due to a lack of attention to the geographic scale of demand; community schemes failed to operate at a sufficient scale and thus could not become viable business ventures. Most of the transaction costs therefore ended up being covered by NGOs directly and long term delivery using this approach proved unsustainable (Cromwell 1996; Tripp and Rohrbach 2001; Wiggins and Cromwell 1995). 
In more recent years, an alternative third phase has emerged, which seeks to develop input supply as an attractive 'small-scale commercial' business through temporary public support. This approach takes into account the high transaction costs for seed producers and distributors in catering for dispersed smallholders who require small individual sales and are serviced by poor infrastructure. It also strengthens the capacities of farmers to test new varieties and seeks to make them well informed consumers of agricultural inputs. This phase has involved the reform of regulations controlling seed production and distribution and changed the objectives of breeding from a 'one size fits all' approach to developing crops that are suitable for specific agro-ecological zones and the specific needs of different groups of farmers (David and Oliver 2002; de Vries and Toenniessen 2001; Kugbei et al. 2000; Lipper et al. 2010; Louwaars 2007; Maredia et al. 1999; Tripp and Rohrbach 2001). The present large scale effort to initiate a 'green revolution' for African smallholders, the Alliance for a Green Revolution in Africa (AGRA), is partly based on an analysis of the input supply constraints that African smallholders are facing and seeks to adopt this approach (Minot et al. 2007).

\section{Agroforestry input supply systems}

The development of tree seed delivery systems for smallholders has been similar to the evolution of crop seed systems, but has lagged by a decade or more. In the first phase in the 1980s and 1990s, National Tree Seed Centres (NTSCs) were established in 21 African Countries supported by overseas development assistance from European countries and Canada (Graudal and Lillesø 2007). While many of the NTSCs were initially intended to support industrial forestry (see Cossalter and Pye-Smith 2003; Evans and Turnbul 2004; Evans 2009 for a discussion of trends), the centres were increasingly designed to supply a range of 'multipurpose' tree species to farmers (Burley and Von Carlowitz 1984; Boland 1992; Graudal and Lillesø 2007; Simons 1997). Studies from Tanzania, Nepal and elsewhere, however, have indicated that only about $10 \%$ of the potential smallholder market for tree seed has been supplied by NTSCs (Aalbæk 2001; Lilles $\varnothing$ et al. 2001a). Like annual crops, tree crops should be suitable for the specific agroecological zones ( $c f$. Burdon 1977, Lilles $\varnothing$ et al. 2001b;
Namkoong et al. 1980) and the needs of different groups of farmers. Increased pressure on NTSCs to completely commercialise their activities in a context of reduced government support has, however, forced most to abandon less profitable activities such as maintaining provenance-level seed sources for many useful agroforestry trees (Graudal and Kjær 1999; Graudal and Lilles $\varnothing 2007)$. In most countries, the role of NTSCs has also been complicated by the fact that they have a role in regulating the activities of other tree seed suppliers; in other words, they have a conflict of interest in playing both 'competitor' and 'regulator' roles (Graudal 1999).

In the second phase of evolution, much of the role of delivery originally assigned to NTSCs was taken over by NGOs, who are now important suppliers of tree seed and seedlings to farmers. Surveys of NGO delivery, however, indicate that a frequent problem is inattention to the genetic quality of the provided planting material (Brandi et al. 2007; Mbora and Lilles $\varnothing$ 2007; Mvula and Lilles $\varnothing$ 2007). In addition, due to limited time horizons and a lack of awareness, many NGO projects have failed to address the longterm maintenance and protection of suitable seed sources (Brandi et al. 2007; Mvula and Lilles $\varnothing 2007$ ). Furthermore, NGOs have generally supplied tree seeds and seedlings on a relief basis (free of charge), which impinges severely on the profitability of market-based commercial seed dealers and private tree nurseries. The small private entrepreneurs that despite this subsidised competition have developed to supply tree planting material in some regions are generally not considered by NGO networks (Brandi et al. 2007; Mvula and Lillesø 2007; Ræbild et al. 2005), who have instead chosen to set up their own nurseries. The NGO approach to tree seed delivery has been very similar to that which they applied to crops (see above) and the observations made by Wiggins and Cromwell (1995) more than a decade ago are therefore also pertinent: the practice of NGOs covering transaction costs makes long term operation unsustainable, as does ignoring nascent entrepreneurial opportunities for local providers.

Agroforestry has not yet entered the third phase for germplasm delivery as adopted in the crop sector, involving support to small-scale commercial production and distribution. Indeed, a major barrier for the further evolution of agroforestry seed delivery systems is that current criteria of definition are based on 
the implicit (but unrealistic) assumption that one central authority is able to control and certify all germplasm sources. This may hinder the development of input supply chains based on small scale entrepreneurs, as we outline below.

\section{A barrier for further development of agroforestry input supply systems}

The purposes of a seed source classification system should be to encourage greater utilisation of superior germplasm and protect consumers from fraudulent sale of inferior materials. In this section, we outline how seed is currently categorised in crop and agroforestry delivery systems. This discussion provides necessary context before we in further sections suggest how the constraints imposed by limitations in current classification can be overcome by the adoption of 'common sense' norms that can contribute to more efficient input supply.

Crop seed—foundation seed and breeding

Tripp (2006) generalised the terms utilised for crop seed (the prevailing schemes are defined by the Organization for Economic Cooperation and Development (OECD) and the Association of Official Seed Certifying Agencies (AOSCA)) to describe the processes that are important for seed delivery: (i) the earliest generations of a variety are referred to as breeding seed, (ii) the generations of seed used by seed producers are termed foundation seed; and (iii) the seed purchased by farmers is commercial seed. In addition, many countries recognize categories such as 'standard seed'; 'truthfully labelled seed'; and 'quality declared seed', which does not require full formal certification (Tripp 2006). The important point to note for the purposes of our current discussion is that there are relatively clear definitions of the entities and links in the breeding, production, and distribution cycle for crop seed. Consequently, the roles of the different actors in the system can be defined clearly and interventions determined accordingly. In particular, it has been possible to identify interventions that favour the involvement of small-scale entrepreneurs in the production and distribution of foundation and commercial seed, and to improve coordination between the different stakeholders that need to be involved to achieve effective, sustainable delivery to smallholders (Minot et al. 2007).

Agroforestry seed—sources and definitions

In contrast to crop seed, there is generally no defined point at which public and large private institutions can breed new materials and then hand this foundation seed over to smaller enterprises for the production and distribution of commercial material. Due to the long and overlapping reproductive cycles, planning for quality and commercial production of agroforestry seed must be done already at the breeding stage.

The 'Forest Seed and Plant Scheme' developed by OECD, which is the prevailing standard for definitions of tree seed sources was established in 1967 and places seed sources into either 'source-identified' (location and altitude recorded) or 'selected' (phenotypically selected at the provenance level) categories (OECD 2009; see also Albrecht (1993)). Although the system is suitable for industrial plantation species, it cannot describe in any operationally meaningful way the majority of tree seed used by tropical smallholders, as most comes from trees that are found scattered in farmland (original source undocumented, may or may not have been selected) or from natural forests (original source known, but unselected). For most indigenous tree species, there is also insufficient knowledge available to determine the boundaries of provenances and the recommendation domains for seed sources, which is a fundamental requirement for the implementation of the OECD approach (OECD 2009, Rule 2.1).

Furthermore, the operation of the OECD system requires a centralised 'designated authority' to certify every commercial seed source in a country, and every seed lot must be authorised and documented by this authority. This presupposes that any designated authority has the capacity to oversee all sources and all seed collection and tree seedling production in a country (OECD 2009, Rule 5.1). Whilst this may be possible for the case of industrial plantation establishment, it is clearly completely unrealistic for the case of smallholder planting, and the implementation of OECD rules would be a barrier to catering for the needs of small-scale farmers.

Although only two African countries are formal members of the OECD scheme, the absence of 
alternative schemes makes it the only standard with which to regulate tree seed systems. The OECD scheme has thus been the key reference for developing national laws and regulations in all African countries with a NTSC (Wolf 1993, see also Barner et al. (1988)).

\section{A classification of sources and input supply to better support smallholder agroforestry}

In contrast to the above, our contention is that the classification system used for agroforestry tree seed must reflect the different types of sources that are actually used by farmers and should facilitate involvement of decentralised producers and distributors. Furthermore, it should enable an understanding of how the biological and logistical characteristics of each source relate to opportunities for potential public-private collaborations that can optimise performance in delivery. Based on such thinking, Dhakal et al. (2005) suggested an alternative typology for tree planting material that accommodates the different types of sources found in landscapes and their multiple functions. The three major components of the input supply chain can be identified as follows:

(i) Sources of reproductive material. Sources can all be categorised into five types (Table 1) whose efficient use requires particular "blends of organisational alternatives" (Minot et al. (2007)) for optimal input supply. Each type of source imposes various biological and logistical constraints on the supply chain, which public support should be tailored to overcome (Graudal and Kjær 1999).

(ii) Seed procurement (initial collection). The actors involved in collection depend on who owns and/or controls the seed sources and their capacity and willingness to make use of material.

(iii) Distribution of seed and seedlings. Some actors are able to afford to give away material during distribution, others makes an income from it. The efficiency and reach of distribution is linked to the extension and marketing methods applied to species, varieties and provenances, and the information given to receivers on germplasm use and quality.
These three components are qualitatively different from each other, in the sense that a source is something physical, while procurement and distribution are 'actions'. The definition, design and establishment of sources are, however, also actions that define the quality of planting material that is available to smallholders.

Particularly important is to understand how various stakeholders are controlling the input supply chain. One useful approach is to apply the dichotomy of 'centralised' or 'decentralised' control to each part of the chain ( $c f$. Graudal and Thomsen 1999). A centralised owner or actor is defined as one of only a limited few that exist in a chain, whilst a decentralised actor is one of many that are present. Clearly, the actors in the centralised-decentralised dichotomy change based on geographic scale, but our view is that this is a useful way to evaluate chain governance and describe entrepreneurial opportunities. Important implicit assumptions are that information flows between actors become increasingly important as systems becomes more decentralised (i.e., not only the flow of seed but also knowledge) and that if many actors are involved in each stage of the chain then the system becomes less likely to fail (possible actor substitution; Barabási (2009)).

Since each of the three components in the input supply chain described by Dhakal et al. (2005) can be managed by either centralised or decentralised actors, a map of possible input supply approaches includes eight $(2 * 2 * 2)$ possible configurations. In practice, we contend that these can be conveniently grouped into three major models that differ mainly with respect to: (i) who controls seed sources, (ii) the type, availability and use of technical knowledge; and (iii) how transaction costs are supported (Box 1). In the 'Government Model', a central authority controls all three components and seed sources are most often located on land controlled by this authority. In the 'NGO Model', the planning of activities is centralised, but control of, and concern with, the quality of seed sources is less rigid. Finally, in the 'Decentralised Model' all activities are handled by decentralised actors, or seed sources are made available by a central authority for use by them.

Each of these major models can be established with the aim of either commercial or free distribution of seed and, for the first two, equivalent models can be found for crop seed both sold and distributed at no 
Table 1 Germplasm source types employed in agroforestry; four are from seed and one is from vegetative material (based on Dhakal et al. 2005)

\begin{tabular}{|c|c|c|c|}
\hline & Brief description & Current use & Timing of seed production/further notes \\
\hline \multicolumn{4}{|c|}{ Seed source type } \\
\hline $\begin{array}{l}\text { Natural } \\
\text { forest }\end{array}$ & $\begin{array}{l}\text { Natural vegetation, ranging from high } \\
\text { forest to woodlands, material of local } \\
\text { origin }\end{array}$ & $\begin{array}{l}\text { Under-utilised, a reservoir of } \\
\text { little-planted, under- } \\
\text { researched, indigenous } \\
\text { species }\end{array}$ & $\begin{array}{l}\text { Producing now. Seed production may be } \\
\text { limited in some forests due to limited } \\
\text { fruit set and difficulties in collection }\end{array}$ \\
\hline Farmland & $\begin{array}{l}\text { Trees on farms, planted or remnants of } \\
\text { natural vegetation, may be local or } \\
\text { non-local (often unknown) origin }\end{array}$ & $\begin{array}{l}\text { Over-utilised, a limited } \\
\text { number of indigenous and } \\
\text { exotic species, quality } \\
\text { criteria not applied }\end{array}$ & $\begin{array}{l}\text { Producing now. Seed yield may be a trade } \\
\text { off with farm function, such as branch } \\
\text { and leaf production for fodder/reducing } \\
\text { competition with agricultural crops }\end{array}$ \\
\hline Plantations & $\begin{array}{l}\text { Trees planted in a plantation or woodlot, } \\
\text { origin not always known }\end{array}$ & $\begin{array}{l}\text { Very few, mainly industrial, } \\
\text { species }\end{array}$ & $\begin{array}{l}\text { Producing now. Quality depends on } \\
\text { origin and diversity of the base } \\
\text { population }\end{array}$ \\
\hline $\begin{array}{l}\text { Seed } \\
\text { orchards }\end{array}$ & $\begin{array}{l}\text { Trees planted in a plantation or woodlot } \\
\text { specifically for seed production, } \\
\text { offspring generally from carefully } \\
\text { selected trees }\end{array}$ & $\begin{array}{l}\text { Very limited use, for a few } \\
\text { exotic species }\end{array}$ & $\begin{array}{l}\text { Producing only after a number of years. } \\
\text { Quality can be improved further by } \\
\text { selective thinning, if performed } \\
\text { carefully }\end{array}$ \\
\hline \multicolumn{4}{|l|}{ Source type } \\
\hline $\begin{array}{l}\text { Vegetative } \\
\text { propagation }\end{array}$ & $\begin{array}{l}\text { Grafts, stem cuttings, micro-cuttings, } \\
\text { somatic embryos or marcots, etc., } \\
\text { propagated from selected clones or } \\
\text { seedlings, genetic diversity often } \\
\text { narrow, may be local or non-local } \\
\text { (potentially unknown) origin }\end{array}$ & $\begin{array}{l}\text { A few exotic fruit tree } \\
\text { selections, unfortunately } \\
\text { also used for unselected } \\
\text { germplasm }\end{array}$ & $\begin{array}{l}\text { Vegetative multiplication protocols } \\
\text { generally take a few years to develop } \\
\text { and adopt }\end{array}$ \\
\hline
\end{tabular}

Table 2 Characteristics of 210 germplasm sources in the Kenya case study

\begin{tabular}{|c|c|c|c|c|c|c|c|c|}
\hline $\begin{array}{l}\text { Type of } \\
\text { source }\end{array}$ & $\begin{array}{l}\text { Exotic } \\
\text { species }^{a}\end{array}$ & $\begin{array}{l}\text { Indigenous } \\
\text { species }^{\mathrm{a}}\end{array}$ & $\begin{array}{l}\text { Total no. of } \\
\text { species }^{\text {a }}\end{array}$ & $\begin{array}{l}\text { Exotic } \\
\text { sources }\end{array}$ & $\begin{array}{l}\text { Indigenous } \\
\text { sources }\end{array}$ & $\begin{array}{l}\text { On } \\
\text { government } \\
\text { land }\end{array}$ & $\begin{array}{l}\text { On communal } \\
\text { and private land }\end{array}$ & $\begin{array}{l}\text { Total no. } \\
\text { of sources }\end{array}$ \\
\hline Farmland & 15 & 7 & 22 & 127 & 9 & 4 & 132 & 136 \\
\hline Natural forest & & 6 & 6 & & 8 & 8 & & 8 \\
\hline Plantation & 14 & 5 & 19 & 22 & 15 & 28 & 9 & 37 \\
\hline Seed orchard & 3 & 1 & 4 & 6 & 1 & 3 & 4 & 7 \\
\hline Vegetative propagation & 6 & & 6 & 22 & & 2 & 20 & 22 \\
\hline Total & 26 & 14 & 40 & 177 & 33 & 45 & 165 & 210 \\
\hline
\end{tabular}

a As several species occur in more than one type of source, numbers for individual categories are different from the overall totals

charge to farmers. For the 'Decentralised Model', non-commercial 'farmer-to-farmer diffusion' of tree germplasm is limited to species and provenances that are already in agricultural landscapes (Brandi et al. 2007; Mvula and Lilles $\varnothing$ 2007; Namoto and Likoswe 2007; Nielsen 1999) or to new introductions of early maturing species. This is different from annual crops that produce seed the same year as planting and where new introductions can quickly be exchanged by farmers after establishment. (Almekinders et al. 2007; Cromwell 1990; Jones et al. 2001; Tripp and Pal 2001). Thus, for the majority of potential tree crops, equivalent farmer-to-farmer production and distribution of seed is a less feasible configuration than for annuals. Furthermore, this approach carries particular risks for outbreeding tree species that are potentially subject to inbreeding depression in farmland, if genetic bottlenecks arise through narrow 
Table 3 Kenya case study germplasm sources by input supply configuration and conformity to OECD criteria

\begin{tabular}{|c|c|c|c|c|c|}
\hline Models & $\begin{array}{l}\text { Number of sources } \\
\text { by model }\end{array}$ & Configuration $^{\mathrm{a}}$ & $\begin{array}{l}\text { Sources per } \\
\text { configuration }\end{array}$ & $\begin{array}{l}\text { Sources conform } \\
\text { to } \mathrm{OECD}^{\mathrm{b}}\end{array}$ & $\begin{array}{l}\text { Sources do not } \\
\text { conform to OECD }\end{array}$ \\
\hline \multirow[t]{4}{*}{ Government model alone } & \multirow[t]{4}{*}{55} & $\mathrm{C}-\mathrm{C}-\mathrm{C}$ & 38 & 31 & 7 \\
\hline & & C-D-C & 7 & 4 & 3 \\
\hline & & $\mathrm{C}-\mathrm{C} / \mathrm{D}-\mathrm{C}$ & 2 & 2 & \\
\hline & & C-C-C/D & 8 & & 8 \\
\hline \multirow[t]{2}{*}{ NGO model alone } & \multirow[t]{2}{*}{12} & D-D-C & 6 & & 6 \\
\hline & & D-C-C & 6 & 3 & 3 \\
\hline \multirow[t]{2}{*}{ Decentralised model alone } & \multirow[t]{2}{*}{66} & D-D-D & 59 & & 59 \\
\hline & & C-D-D & 7 & 2 & 5 \\
\hline $\begin{array}{l}\text { NGO model and } \\
\text { decentralised model }\end{array}$ & 71 & D-D-C/D & 71 & & 71 \\
\hline \multirow{2}{*}{$\begin{array}{l}\text { Government model and } \\
\text { decentralised model }\end{array}$} & \multirow[t]{2}{*}{6} & C-D-C/D & 5 & 5 & \\
\hline & & C-C/D-C/D & 1 & 1 & \\
\hline Total & 210 & & 210 & 48 & 162 \\
\hline
\end{tabular}

${ }^{a}$ Some of the chains are simultaneously utilised by more than one type of actor (C/D), leading to the same source participating in more than one configuration

${ }^{\mathrm{b}}$ Conforms to OECD if established on government land or with advice from the Kenyan NTSC

diffusion (Dawson et al. 2009; Dhakal et al. 2005). A commercial 'Decentralised Model' introducing new species and varieties therefore requires special attention to how tree seed sources are utilised as breeding, foundation, and commercial seed in the input supply chains.

\section{The Kenya case study}

To test the utility of the above typology, we applied it to an assessment of supply chains for smallholder tree planting material in the Mount Kenya region of Kenya. Survey work was undertaken as part of the Improved Seed Supply for Agroforestry in African Countries (ISSAAC) project, a Danida supported programme implemented by Forest and Landscape Denmark (FLD) and the World Agroforestry Centre (ICRAF). The survey area was chosen because preliminary observations suggested that it had a high concentration of different sources for agroforestry seed and seedlings (Mbora and Simons 2003). Survey involved collaboration with the Nairobi office of the Registrar of NGOs, the Kenya Forest Research Institute, government officers at district and divisional levels (for forestry, agriculture, livestock, and soil and water conservation) and the Nairobi offices of several NGOs. Extension agents from NGOs, government and ICRAF helped to identify involved farmers and farmer groups. Local respondents in individual and group interviews included Kenya Forest Service officers, farmer-group chairpersons', individual farmers and extension officers. Field checks were carried out on a subset of seed sources identified during interviews.

During survey, we used the following classification: (i) the Kenyan NTSC (known as the Kenya Forest Seed Centre, or KFSC) and government agencies were recorded as formal, centralised actors, (ii) NGOs, church groups and other community-based organisations were considered to be informal, centralised stakeholders; and (iii) farmer groups and individual farmers were classified as informal, decentralised participants, as were schools and seed dealer associations. Sources located on government land were classified as centralised (and under formal control of seed regulations), while sources on communal and private land were considered decentralised (not normally established under the supervision of government authorities).

In total, we were able to identify 210 sources for seed and vegetative materials that were established and are being used by various actors. We classified all sources (Table 2) into the five categories already described (Table 1). Sources for 40 species were identified, of which 14 were indigenous trees. The 
Box 1 Eight configurations of 'Source-Procurement-Distribution' input supply chains, grouped into three major models (C indicates a centralised actor, $\mathrm{D}$ decentralised)

A. Centralised configurations, the 'Government model'

Sources are controlled by a central authority, and most often established on the basis of central planning. In countries with a National Tree Seed Centre, technical knowledge on seed is available to this authority. In these configurations, the transaction costs of bringing seed from source to smallholders are covered by the central authority mainly through government funds or development assistance. Sales of seed are predominantly to other centralised actors

1 and 2. The C-C-C (fully centralised) and the C-D-C (centralised, with contracted procurement) configurations. Seed sources and seed distribution are controlled by a central authority

3. The C-C-D (centralised sources and procurement, with decentralised distribution) configuration. Seed procurement is carried out by government employees or contractors, while distribution is carried out by decentralised actors

B. Centralised configurations, the 'NGO model'

Sources are not necessarily controlled by a central authority, but their use most often supply driven by NGOs. Technical knowledge on seed (e.g., on provenance performance differences) is not necessarily available or used. In these configurations, the transaction costs are mainly covered by an NGO through project funds. Sales of seed are predominantly to other centralised actors

4 and 5. The D-C-C (centralised out-grower, procurement by the distributor) and the D-D-C (centralised out-grower, procurement by the grower) configurations. The control of distribution resides with a central agent in both configurations. Procurement (collection) is undertaken by the controlling agent in the D-C-C configuration or subcontracted in the D-D-C configuration. The two configurations are probably the most commonly utilised in agroforestry, in which NGOs distribute seed and seedlings collected from farmers' land

6. The D-C-D (decentralised sources and distribution, centralised procurement) configuration. Procurement is

controlled by a central actor, whereas distribution is carried out by decentralised agents. The most likely occurrence is when a NGO sells or gives away planting material to farmers and local community groups

C. Decentralised configurations, the 'Decentralised model'

Sources are not necessarily controlled by a central authority, but their use is in principle demand driven by customers of seed and seedlings. Technical knowledge on seed is not necessarily available or used. In these configurations, the transaction costs are covered directly by the actors involved. There is the expectation of profitable sales (commercial dealers) or alternatively material is diffused as gifts (non-commercial, reciprocal exchange possible) between farmers

7 and 8 . The D-D-D (fully decentralised) and the C-D-D (centralised sources, decentralised procurement and distribution) configurations. Sources may be located on government land (C-D-D) or on private/communal land (D-D-D). Commercial decentralised configurations are currently being promoted for innovation in crop seed systems in the tropics

most frequent source type was farmland (136 counts), though these stands mostly consisted of small number of trees with modest seed production. Plantation sources established by the Kenya Forest Service were considerably fewer but the next most common after farmland, with natural forest (for indigenous species) and seed orchard sources (of genetically superior germplasm) relatively rare. The low numbers for these last two sources is an indication of limited long term coordination and investment in tree seed systems. Vegetative propagation was used as a source for mass production of cultivars of a few exotic fruit species such as mango, citrus, avocado and papaya.

We next grouped the identified sources into supply chain configurations based on our classification (Box 1). We also determined whether sources would if placed within the current OECD scheme conform to the classification and control systems thereby imposed (Table 3). Our survey revealed that many sources fit into two models, either (i) NGO and decentralised; or (ii) government and decentralised, of which by far the largest overlap is in the former case (72 sources compared to six sources). In total, the decentralised model applies to 137 sources $(65 \%)$, the NGO model to 83 sources $(40 \%)$ and the government model to 61 sources (29\%; percentages do not add to 100 because of overlap), within which last category all natural forest sources and most plantation sources are included.

Of the 210 sources, only 48 (less than a quarter) would conform to OECD criteria. Forty-five of these were located on government land and thus in principle established following the regulations set by KFSC, while only three were established in private or communal land with the assistance of NGOs in collaboration with the KFSC. The 
remaining 162 sources cannot be said to have been established under the supervision of a central authority and are therefore excluded from OECD approval as seed sources.

We also collected commercial data to see which sources could play a part in developing more efficient entrepreneurial systems for supply. Overall, seed was sold from $67 \%$ of sources, varying from $29 \%$ of cases for sources categorised under the decentralised model (alone) to $95 \%$ of sources falling into both the NGO and decentralised models. Seed was sold from $75 \%$ of sources under the government model (alone). Farmers involved in the sale of seed used a number of avenues: they sold seed in small packets during agricultural trade fairs, from their homes, during chief's meetings and on market days. Often they were assisted by extension agents who procured seed and linked farmers to customers. Most non-commercial seed sources consisted of fodder shrubs (particularly Calliandra calothyrsus and Leucaena trichandra; Mbora and Lilles $\varnothing$ 2007) promoted originally in the region by ICRAF under a 'no-cost' to farmers' and farmer-to-farmer diffusion approach (Kiptot et al. 2006; Place et al. 2009); about $60 \%$ of these sources are still distributed in this way.

\section{Discussion}

Our theoretical discourse and case study demonstrate the applicability of a five-category source and threecategory delivery system notation (source-procurement-distribution, based on centralised or decentralised actors) for categorising tree germplasm inputs to smallholders. In our Kenyan example, all three major delivery models (government, NGO and decentralised) apply, with the last the most common. The first two models carry particular disadvantages: the government model has a limited capacity to reach smallholders; and the NGO model lacks incentives for long term planning and for giving proper attention to quality and site matching (Brandi et al. 2007). In the context of negligible public support and subsidised competition, it is remarkable that a nascent commercial decentralised model for tree seed delivery exists at all in the region. Our discourse and Kenyan example also demonstrate a discord between currently available and accepted classification and regulation (e.g., OECD) schemes for tree seed delivery and what takes place in the field; for example, more than three-quarters of tree seed sources in our Kenya survey do not conform to OECD rules.

We do not have data to indicate how relevant our case study is to other regions-Mount Kenya has a wide variety and high concentration of different seed sources-but it provides hypotheses for further testing elsewhere. We anticipate that farmland seed sources will be by far the dominant source type in sub-Saharan Africa, and that seed orchard and natural forest sources will be relatively rarely used. We furthermore anticipate that vegetative propagation will generally be applied to only a few high value fruit species. We expect that the same major input supply models will be identified elsewhere, with decentralised and NGO models most common. In the former case, we expect entrepreneurial involvement to be highest in areas of both high potential for growing tree crops and high demand for agroforestry products.

The sources and supply chain models described above can be explored in the context of the required innovations in organisations, processes and policies needed for more effective functioning (Larsen et al. 2009). The five seed source types we adopt in our classification provide different opportunities and constraints for public institutions, NGOs and private enterprises in terms of access to breeding material, quality and choice (Dhakal et al. 2005), and different models for procurement and distribution have particular strengths and weaknesses. If it can be assumed that, based on altruistic and/or commercial reasons, the various actors involved in tree seed delivery to smallholders have the same goal in delivering good quality planting material (Graudal and Kjær 1999), then we believe opportunities exist for reallocating current roles to improve supply.

In our opinion, the role of NGOs should be to support existing entrepreneurs rather than unfairly undercutting them through short-term free handouts of germplasm. Our Kenyan case study provides clear indications that small-scale entrepreneurs have the potential to become important producers and distributors of tree seed and seedlings if such disincentives are removed. The development of public-private collaborations to support smallholders' inputs should start by embedding seed from improved sources into supply chains. Support from NGOs should therefore come through greater focus on the establishment of good quality (rather than 
Box 2 Interventions required for specific source types (as described in Table 1)

1. Seeds from farmland sources are best collected and distributed by small-scale enterprises. Collection and distribution can be organised at a decentralised level, but requires knowledge (that can be provided by NTSCs) and application of common sense norms to ensure genetic quality, in particular taking into account breeding systems and genotype-environment interactions (Dawson and Were 1997; Lillesø et al. 2001a). Special care must be taken to widen genetic quality through public support for the development of networks of producers for exchange and pooling of material

2. Natural forest sources contain a large number of underutilised indigenous species. To mobilise the genetic potential of these species for farmers requires skilled collection of relatively large amounts of seed. This can only be justified on economic grounds if material is distributed to many users. NTSCs should coordinate collection together with several NGOs and networks of small-scale nurseries

3. Seed collection of species in plantations can be carried out by NTSCs or private specialised small-scale collectors for distribution to networks of small-scale nurseries. Quality can be ensured by applying common sense norms

4. Production of improved seed in seed orchards should be scaled up to more sources and species through low-input breeding initiatives supported by NTSCs (Kjær et al. 2006). Establishment, collection and distribution can be organised at a decentralised level, but would require insurance until production begins as well as efficient distribution networks to ensure a return on the long term investment

5. Wider use of vegetative propagation of fruit trees requires institutional innovations in developing new methods. Clones may be produced centrally, but multiplication should be organised at a decentralised level to save the costs of transportation. Support by research institutions, NTSCs and NGOs is required to ensure a return on investment

unknown quality) seed sources. It should extend to providing business training to entrepreneurial seed dealers and tree nurseries, and should support networks of producers and distributors of seed and seedlings (Dawson et al. 2009; Kindt et al. 2006). The role of NGOs is also to support the development of smallholder product value chains through better linkages with markets; this in turn will drive better input supply chains.

NTSCs should be knowledge brokers of technical information to existing entrepreneurs and other producers on all aspects of seed quality, production and procurement, rather than providing seed themselves; this involves a strong training role. NTSCs should, however, also be involved in supplying high quality 'starter' germplasm, especially of useful (but underutilised) indigenous species from natural forest land, either through direct collection into efficient input supply chains or indirectly through establishment of seed orchards. To prevent unfair competition it is, however, essential that NTSCs decouple commercial seed enterprise from the normative functions of providing policies, legislation, and regulation of the market and of providing independent advice and guidance to users. Innovations specific to developing new collaborative models that ensure seed of good genetic quality of a wide range of species is distributed efficiently to smallholders from relevant sources are given in Box 2. They relate divisions of labour between actors based on their comparative advantages.

\section{Conclusion}

There is significant potential for increasing the productivity of agroforestry systems through improved seed supply chains for smallholder tree planters. Innovation requires a considered interpretation of the seed sources involved and their relative importance, and an alternative regulatory framework to the OECD scheme. For crop seed, many countries recognize categories such as 'standard seed', 'truthfully labelled seed' and 'quality declared seed' that are less rigid forms of certification. The seed source classification that we have presented here could be the backbone of a more flexible and useful scheme for trees.

Profound change is required in the roles played be different actors in agroforestry input supply chains. Government organisations and NGOs must change from using production figures as sole targets for their planning and instead focus on how they can help private actors function as market players. In particular, the current NGO model has little justification and free seed impedes the development of decentralised smallscale enterprise models for tree seed in the same way as it does for crop seed (Graudal and Lillesø 2007; Sperling and McGuire 2010). Needed innovations 
provide huge potential for action-research, which we hope this article will help stimulate and guide.

Acknowledgments The authors would like to acknowledge the contributions of all those involved in the case study, particularly farmers and field staff of NGOs and government agencies, as well as staff at ICRAF and the Kenya Forestry Seed Centre. Danida provided funding to both FLD and ICRAF. We are grateful to the G.B. Hartmanns Fond Foundation for supporting the first author, JPBL, in writing this document as part of an assignment documenting tree seed supply in the tropics. The views expressed in this paper are those of the authors and not necessarily the positions of the institutions they represent.

Open Access This article is distributed under the terms of the Creative Commons Attribution Noncommercial License which permits any noncommercial use, distribution, and reproduction in any medium, provided the original author(s) and source are credited.

\section{References}

Aalbæk A (2001) Access to planting material as a major constraint to farmer tree planting and nursery production in Tanzania. PhD Dissertation, Department of Economics and Natural Resources, Royal Veterinary and Agricultural University, Denmark

Albrecht J (1993) Forest seed handling. In: Pancel L (ed) Tropical forestry handbook, vol 1. Springer, Berlin, pp 381-462

Almekinders CJM, Thiele G, Danial DL (2007) Can cultivars from participatory plant breeding improve seed provision to small-scale farmers? Euphytica 153:363-372

Barabási AL (2009) Scale-free networks: a decade and beyond. Science 325:412-413

Barner H, Olesen K, Wellendorf H (1988) Classification and selection of seed sources. Lecture Note B.1. Danida Forest Seed Centre, Humlebaek, Denmark. http://en.sl.life.ku. $\mathrm{dk} /$ Publikationer/Udgivelser/DFSC/DFSCB1.aspx?katid= \{B47F524A-1CA4-4C84-982C-A3E55EAE93FA. Last accessed on November 7, 2010

Boland DJ (1992) Proceedings of the international consultation on the development of the ICRAF MPT-Germplasm Resource Centre. Nairobi 2-5 June 1992. International Research Council for Research in Agroforestry, Nairobi, Kenya

Brandi E, Lillesø JPB, Moestrup S, Kisera HK (2007) Do organisations provide quality seed to smallholders? A study on tree planting in Uganda, by NGOs and CBOs. Development and Environment 8-2007. Forest \& Landscape Denmark. http://en.sl.life.ku.dk/Publikationer/Udgivelser/ AndreVidenskabelige/DE8 .asp $x$ ?katid $=\{$ C6BFAD94-B8E E-49D4-9419-85C702419AFC $\}$. Last accessed on November 7, 2010

Burdon RD (1977) Genetic correlation as a concept for studying genotype-environment interaction in forest tree breeding. Silvae Genet 25(5-6):168-175
Burley J, von Carlowitz P (1984) Multipurpose tree germplasm. Proceedings, recommendations and documents of a planning workshop to discuss International Cooperation held at the National Academy of Sciences. Washington D.C., U.S.A., June 1983

Cossalter C, Pye-Smith C (2003) Fast-wood forestry myths and realities. Center for International Forestry Research. Bogor, Indonesia. http://www.cifor.cgiar.org/Knowledge /Publications/Detail?pid=1257. Last accessed November 7, 2010

Cromwell E (1990) Seed diffusion mechanisms in small farmer communities. Lessons from Asia, Africa, and Latin America. Network Paper 21. ODI Agricultural Administration (Research and Extension) Network. Overseas Development Institute, Wallington, UK

Cromwell E (1996) Governments, farmers and seeds in a changing Africa. Overseas Development Institute/CAB International, Wallington, UK

David S, Oliver B (2002) Business skills for small-scale seed producers: handbooks for small-scale seed producers: a trainers' guide. Handbook 3. Network on Bean Research in Africa. Occasional Publications Series, No. 36. CIAT, Kampala, Uganda. http://webapp.ciat.cgiar.org/africa/pdf/ handbook_3_english.pdf. Last accessed November 7, 2010

Dawson I, Were J (1997) Collecting germplasm from treessome guidelines. Agrofor Today 9(2):6-9

Dawson IK, Lengkeek A, Weber JC, Jamnadass R (2009) Managing genetic variation in tropical trees: linking knowledge with action in agroforestry ecosystems for improved conservation and enhanced livelihoods. Biodivers Conserv 18:969-986

de Vries J, Toenniessen G (2001) Securing the harvest: biotechnology, breeding and seed systems for African crops. CABI Publishing, Nairobi, Kenya

Dhakal LP, Lillesø JPB, Kjær ED, Jha PK, Aryal HL (2005) Seed sources of agroforestry trees in a farmland contexta guide to tree seed source establishment in Nepal. Development and Environment 1-2005, Forest \& Landscape Denmark. http://en.sl.life.ku.dk/Publikationer/Udgi velser/AndreVidenskabelige/DE1 .aspx ?katid $=\{\mathrm{C} 6 \mathrm{BFAD}$ 94-B8EE-49D4-9419-85C702419AFC . Last accessed November 7, 2010

Evans J (ed) (2009) Planted forest. Uses, impacts and sustainability. $\mathrm{CAB}$ International $(\mathrm{CABI})$ and Food and Agricultural Organisation (FAO), Rome, Italy

Evans J, Turnbul JW (2004) Plantation forestry in the tropics. Oxford University Press, Oxford, UK

Friis-Hansen E (2000) Agricultural policy in Africa after Adjustment. CDR Policy Paper. Centre for Development Research. September 2000

Garrity DP (2004) Agroforestry and the achievement of the Millennium Development Goals. Agrofor Syst 61:5-17

Graudal L (1999) The functions and role of a national tree seed programme. In: Eyog-Matig O, Kigomo B, Boffa JM (eds) 2001. Recent research and development in forest genetic resources. Proceedings of the training workshop on the conservation and sustainable use of forest genetic resources in Eastern and Southern Africa, 6-11 December 1999, Nairobi, Kenya. International Plant Genetic resources Institute, Nairobi, Kenya, pp 215-222 
Graudal L, Kjær ED (1999) Challenges facing national tree seed programmes. Economics and sustainability of tree seed centres. In: Eyog-Matig O, Kigomo B, Boffa J-M (eds) 2001. Recent research and development in forest genetic resources. Proceedings of the training workshop on the conservation and sustainable use of forest genetic resources in Eastern and Southern Africa, 6-11 December 1999, Nairobi, Kenya. International Plant Genetic resources Institute, Nairobi, Kenya, pp 15-28

Graudal L, Lillesø JPB (2007) Experiences and future prospects for tree seed supply in agricultural development support-based on lessons learnt in Danida supported programmes 1965-2005. Danida Working Paper-April 2007. Ministry of Foreign Affairs of Denmark. Copenhagen, Denmark. http://www.danidadevforum.um.dk/NR/ rdonlyres/0721964C-859D-49BA-95E4-16B3D3355DB2/ 0/Experienceandfutureprospects.pdf. Last accessed November 7, 2010

Graudal L, Thomsen A (1999) Institutional development in forest genetic resources. In: Eyog-Matig $\mathrm{O}, \mathrm{Ki}-$ gomo B, Boffa J-M (eds) 2001. Recent research and development in forest genetic resources. Proceedings of the training workshop on the conservation and sustainable use of forest genetic resources in Eastern and Southern Africa, 6-11 December 1999, Nairobi, Kenya. International Plant Genetic resources Institute, Nairobi, Kenya, pp 195-199

Hazell P, Poulton C, Wiggins S, Dorward A (2007) The future of small farms for poverty reduction and growth. 2020 Discussion Paper No. 42. International Food Policy Research Institute, Washington, DC. http://www.ifpri.org/publication /future-small-farms-poverty-reduction-and-growth. Last Accessed November 7, 2010

Jones RB, Audi PA, Tripp R (2001) The role of informal seed systems in disseminating modern varieties. The example of pigeonpea from a semi-arid area of Kenya. Exp Agr 37:539-548

Kindt R, Lillesø JPB, Mbora A, Muriuki J, Wambugu C, Frost W, Beniest J, Aithal A, Awimbo J, Rao S, HoldingAnyonge C (2006) Tree seeds for farmers: a toolkit and reference source. World Agroforestry Centre, Nairobi. http://www.worldagroforestry.org/treesandmarkets/tree\% 20seeds/Documents\%20of\%20Toolkit/Toolkit.htm. Last accessed November 7, 2010

Kiptot E, Franzel S, Hebinck P, Richards P (2006) Sharing seed and knowledge: farmer to farmer dissemination of agroforestry technologies in western Kenya. Agrofor Syst 68:167-179

Kjær ED, Dhakal LP, Lillesø JPB, Graudal L (2006) Application of low input breeding strategies for tree improvement in Nepal. In: Fikret KI (ed) Low input breeding and genetic conservation of forest tree species. Proceedings from IUFRO conference October 2006, Turkey, pp 103-109

Kugbei S, Turner M, Witthaut P (eds) (2000) Finance and management of small-scale seed enterprises. Proceedings of a workshop. 26-30 Oct 1998, Addis Ababa, Ethiopia. ICARDA

Larsen K, Kim R, Theus F (2009) Agribusiness and innovation systems in Africa. The World Bank, Washington DC, USA. http://info.worldbank.org/etools/docs/library/252086/WBI\%
20Agribusiness \%20and\%20Innovation.pdf. Last accessed November 7, 2010

Lilles $\varnothing$ JPB, Dhakal LP, Jha PK, Aryal HL (2001a) Addressing smallholders' demand for propagation material of woody species. Part I: Analysis and Strategy proposal. DFSC Case Study No. 3. TISC Document No. 104. Danida Forest Seed Centre, Humlebaek, Denmark. Tree Improvement and Silviculture Component, Kathmandu, Nepal. http://en.sl.life.ku.dk/Publikationer/Udgivelser/DF SC/DFSCCS3 . aspx ?katid $=\{$ B47F524A-1CA4-4C84-982 C-A3E55EAE93FA\}. Last accessed November 7, 2010

Lilles $\varnothing$ JPB, Dhakal LP, Shrestha TB, Nayaju RP, Shrestha R, Kjaer ED (2001b) Tree Planting Zones in Nepal—an ecological approach based on vegetation types. DFSC Case Study No. 1. TISC Technical Paper No. 103. Danida Forest Centre, Humlebæk. Tree Improvement and Silviculture Component, Kathmandu. http://en.sl.life.ku.dk/ Publikationer/Udgivelser/DFSC/DFSCCS1.aspx ?katid= \{B47F524A-1CA4-4C84-982C-A3E55EAE93FA\}. Last accessed November 7, 2010

Lipper L, Anderson CL, Dalton TJ (eds) (2010) Seed trade in rural markets: implications for crop diversity and agricultural development. Food and Agricultural Organisation of the United Nations, Rome, Italy and Earthscan, London, UK

Louwaars N (2007) Seeds of confusion; the impact of policies on seed systems. PhD dissertation, Wageningen University, Wageningen, The Netherlands. http://edepot.wur.nl /121915. Last accessed November 7, 2010

Maredia M, Howard J, Boughton D, Naseem A, Wanzala M, Kajisa K (1999) Increasing seed system efficiency in Africa: concepts, strategies and is'sues. MSU international development working paper no. 77. MSU International Department of Agricultural Economics. Michigan State University. USA. http://ageconsearch.umn.edu/ handle/54578. Last accessed November 7, 2010

Mbora A, Lilles $\varnothing$ JPB (2007) Sources of tree seed and vegetative propagation of trees around Mt. Kenya. Development and Environment 9-2007. Forest \& Landscape Denmark. http://en.sl.life.ku.dk/Publikationer/Udgivelser /AndreVidenskabelige/DE9.aspx katid $=\{$ C6BFAD94-B8 EE-49D4-9419-85C702419AFC . Last accessed November 7, 2010

Mbora A, Simons A (2003) Annotated inventory of agroforestry related work around Mt. Kenya (1983-2002). World Agroforestry Centre, Nairobi, Kenya

Minot N, Smale M, Eicher C, Jayne T, Kling J, Horna D, Myers R (2007) Seed development programs in sub-Saharan Africa: a review of experiences. Rockefeller Foundation. Nairobi, Kenya. http://www.aec.msu.edu/fs2/responses/Jayne_Mye rs_African_seed_review.pdf. Last accessed November 7, 2010

Mvula PM, Lilles $\varnothing$ JPB (2007) Tree seedling growers in Malawi-who, why and how? Development and Environment 5-2007. Forest \& Landscape Denmark. http://en. sl.life.ku.dk/Publikationer/Udgivelser/AndreVidenskabeli ge/DE5 .aspx ?katid= $\{$ C6BFAD94-B8EE-49D4-9419-85C 702419AFC . Last accessed November 7, 2010

Namkoong G, Barnes RD, Burley J (1980) A philosophy of breeding strategy for tropical forest trees. Tropical forestry papers 16. Unit of Tropical Silviculture, 
Commonwealth Forestry Institute, University of Oxford, University of Oxford, UK

Namoto M, Likoswe MG (2007) Case studies of nurseries in Malawi. Forest \& Landscape Working Papers no. 20-2007. Forest \& Landscape Denmark. http://en.sl.life. ku.dk/Publikationer/Udgivelser/AndreVidenskabelige/FL WP20.aspx ?katid $=\{$ C6BFAD94-B8EE-49D4-9419-85C7 02419AFC . Last accessed November 7, 2010

Nielsen F (1999) Issues in the utilisation of indigenous knowledge in agroforestry research. Ph.D Thesis at Institute of Geography, University of Copenhagen, Copenhagen, Denmark

OECD (2009) OECD scheme for the certification of forest reproductive material moving in international trade. Organisation for Economic Co-operation and Development. Trade and Agricultural Directorate, Paris, France. http://www.oecd.org/dataoecd/38/17/43347527.pdf. Last accessed on November 7, 2010

Place F, Roothaert R, Maina L, Franzel S, Sinja J, Wanjiku J (2009) The impact of fodder trees on milk production and income among smallholder dairy farmers in East Africa and the role of research. ICRAF Occasional Paper No. 12. World Agroforestry Centre, Nairobi. http://vslp.org/2010/08/24/the-impactof-fodder-trees-on-milk-production-and-income-among-sma llholder-dairy-farmers-in-east-africa-and-the-role-of-research I. Last accessed November 7, 2010

Ræbild A, Bassirou B, Lillesø JPB, Yago EL, Damas P (2005) Farmers' planting practices in Burkina Faso. A survey carried out by the project 'Improved Seed Supply for Agroforestry in African Countries' (ISSAAC). Forest \& Landscape working papers no. 5. 200460 pp. Forest \& Landscape Denmark. http://en.sl.life.ku.dk/Publikationer /Udgivelser/AndreVidenskabelige/FLWP5.aspx?katid $=\{\mathrm{C} 6$ BFAD94-B8EE-49D4-9419-85C702419AFC . Last accessed November 7, 2010

Simons A (1997) Advance proceedings of the international workshop on policy aspects of tree germplasm demand and supply organised at ICRAF. Nairobi, Kenya, 6-8 October 1997. International Research Council for Research in Agroforestry, Nairobi, Kenya
Sperling L, McGuire SJ (2010) Persistent myths about emergency seed aid. Food Policy 35:195-201

Tripp R (2001) Seed provision \& agricultural development: the institutions of change. Overseas Development Institute, London, UK

Tripp R (2006) The case for foundation seed enterprises in Sub-Saharan Africa. Overseas Development Institute, London, UK

Tripp R, Pal S (2001) The private delivery of public crop varieties: rice in Andhra Pradesh. World Dev 29(1):103-117

Tripp R, Rohrbach D (2001) Policies for African seed enterprise. Dev Food Policy 26:147-161

White R, Eicher CK (1999) NGOs and the African Farmer. Staff Paper No. 99-01. Department of Agricultural Economics, Michigan State University, East Lansing, Michigan. http:// ageconsearch.umn.edu/bitstream/11532/1/sp99-01.pdf). Last accessed on November 7, 2010

Wiggins S, Cromwell E (1995) NGOs and seed provision to smallholders in developing countries. World Dev 23: $413-422$

Wolf H (ed) (1993) Seed procurement and legal regulations for forest reproductive material in tropical and subtropical countries. Proceedings of an international symposium held from 04-10 October 1992 in Nairobi, Kenya. GTZForestry Seed Centre Muguga, Nairobi, Kenya

World Bank (2007) World development report 2008, Agriculture for Development. The International Bank for Reconstruction and Development/The World Bank. Washington DC, USA. http://econ.worldbank.org/WBSI TE/EXTERNAL/EXTDEC/EXTRESEARCH/EXTWDR S/EXTWDR2008/0,,menuPK:2795178 pagePK:641677 $02 \sim$ piPK:64167676 theSitePK:2795143,00.html. Last accessed November 7, 2010

Zomer RJ, Trabucco A, Coe R, Place F (2009) Trees on farm: analysis of global extent and geographical patterns of agroforestry. ICRAF Working Paper no. 89. Nairobi, Kenya: World Agroforestry Centre. http://www.worldagroforestry centre.org/newsroom/for_journalists/agroforestry_assessme nt_report. Last accessed November 7, 2010 